\title{
Pengaruh Perendaman Alkali, Kalium Permanganat, dan Hidrogen Peroksida terhadap Perubahan Diameter Serat Sabut Kelapa Sebagai Bahan Komposit Ramah Lingkungan
}

\author{
Muhammad Arsyad ${ }^{1, a}$ dan Rudy Soenoko ${ }^{2, b}$ \\ ${ }^{1}$ Jurusan Teknik Mesin, Politeknik Negeri Ujung Pandang, Jalan Perintis Kemerdekaan KM.10 \\ Tamalanrea Makassar, 90245, Indonesia \\ ${ }^{2}$ Jurusan Teknik Mesin, Universitas Brawijaya, Jalan M.T.Haryono No. 167, Malang, 65145, Indonesia \\ a arsyadhabe@poliupg.ac.id \\ brudysoen@ub.ac.id
}

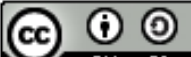

Abstract-This study aims to determine the effect of alkali treatment and hydrogen peroxide on the change in diameter of coconut fiber as an environmentally friendly composite material. This research was carried out with several stages, namely: preparation of materials and tools, treatments, measurement of diameter, analysis, and discussion. Materials and equipment used are coconut fiber, alkaline solution, hydrogen peroxide solution, distilled water, a set of immersion media, and digital microscopes. Coconut fiber was soaked in alkaline solution with $10 \%$ concentration for $1,3,5,7,9$, and 11 hours, then dried in a furnace at $90^{\circ} \mathrm{C}$ for 5 hours. Furthermore, coconut fiber was soaked again in potassium permanganate solution with a concentration of $0.5 \%$ for $1,3,5,7,9$, and 11 hours, then dried in a furnace at $90^{\circ} \mathrm{C}$ for 5 hours. Then the coconut fiber was soaked again in a hydrogen peroxide solution with a concentration of $10 \%$ for $1,3,5,7,9$, and 11 hours, then dried in a furnace at $90^{\circ} \mathrm{C}$ for 5 hours. After that, using a digital microscope the diameter of coconut fiber is measured. Based on the measurement results, it was concluded that the diameter of coconut fiber was degraded in diameter after soaking in alkaline solution, potassium permanganate, and hydrogen peroxide. The highest percentage reduction in diameter was $58.08 \%$ in the third treatment.

Keywords- Diameter; chemical treatment; compositet; environment benighned

Abstrak-Penilitian ini bertujuan untuk menentukan pengaruh perlakuan alkali dan hidrogen peroksida terhadap perubahan diameter serat sabut kelapa sebagai material komposit ramah lingkungan. Penelitian ini terlaksana dengan beberapa tahapan yaitu: persiapan bahan dan alat, perlakuan, pengukuran diameter, analisa, dan pembahasan. Bahan dan peralatan yang digunakan yaitu serat sabut kelapa, larutan alkali, larutan hidrogen peroksida, aquades, seperangkat media perendaman, dan mikroskop digital. Serat sabut kelapa direndam dalam larutan alkali dengan konsentrasi $10 \%$ selama $1,3,5,7,9$, dan 11 jam, kemudian dikeringkan dalam tungku pada $90^{\circ} \mathrm{C}$ selama 5 jam. Selanjutnya, serat sabut kelapa direndam kembali dalam larutan kalium permanganat dengan konsentrasi $0,5 \%$ selama $1,3,5,7,9$, dan 11 jam, kemudian dikeringkan dalam tungku pada $90^{\circ} \mathrm{C}$ selama 5 jam. Kemudian serat sabut kelapa direndam lagi dalam larutan hidrogen peroksida dengan konsentrasi $10 \%$ selama 1, 3, 5, 7, 9, dan 11 jam, kemudian dikeringkan dalam tungku pada $90^{\circ} \mathrm{C}$ selama 5 jam. Setelah itu, dengan menggunakan mikroskop digital diameter serat sabut kelapa diukur. Berdasarkan hasil pengukuran tersebut disimpulkan bahwa diameter serat sabut kelapa mengalami degradasi diameter setelah direndam dalam larutan alkali, kalium permanganat, dan hidrogen peroksida. Persentasi tertinggi pengurangan diameter diperoleh sebesar $\mathbf{5 8 , 0 8 \%}$ pada perlakuan ketiga.

Kata Kunci-Diameter, perlakuan kimia;, komposit, ramah lingkungan

\section{Pendahuluan}

Kebanyakan masyarakat Indonesia masih memahami bahwa serat alam tidak terlalu banyak manfaatnya, bahkan tidak sedikit yang menganggapnya sebagai bahan yang tak berguna yang pada akhirnya akan menjadi sampah. Namun, dengan kemajuan ilmu pengetahuan dan teknologi, serat alam dapat diolah menjadi bahan bermanfaat menjadi material teknik. Kelebihan-kelebihan yang dimiliki serat alam seperti: banyak tersedia, banyak jenisnya, biaya produksi rendah, elastis, ramah lingkungan. Proses pembuatan komposit berpenguat serat alam relatif lebih murah, dan ramah 
lingkungan. Secara ekologi, pada saat proses pembuatan menghasilkan kadar karbon yang rendah. Selain itu, komposit berbasis serat alam ini dapat didaur ulang untuk digunakan kembali, meskipun kinerjanya berkurang. Berdasarkan kelebihan-kelebihan tersebut, maka serat alam kembali dilirik oleh peneliti untuk dijadikan sebagai bahan penguat komposit. Dalam suatu hasil penelitian, diperoleh bahwa komposit berpenguat serat alam memiliki kekuatan 40\% lebih kuat dan lebih ringan daripada komposit berpenguat serat gelas. Bila digunakan pada kendaraan, maka lebih ringan berarti mengurangi bobot total kendaraan, sehingga pemakaian bahan bakar bisa lebih hemat [1]. Penggunaan serat alam ini akan sejalan dengan program lingkungan pemerintah yaitu "go green". Serat alam juga memiliki kekurangan seperti: penyerapan air tinggi, kekuatannya rendah, sulit bersifat hydrophilic, kualitasnya tidak seragam. Serat alam yang banyak dikembangkan sebagai material komposit seperti : sisal, flex, hemp, jute, rami, sabut kelapa [2].

Karakteristik komposit berpenguat serat alam tergantung pada serat, penyebaran serat, dan interaksi antara serat dengan matriks. Selain perlakuan kimia yang dapat menentukan sifat suatu komposit yang dihasilkan, dipengaruhi juga oleh beberapa kondisi serat seperti bagaimana serat itu diperoleh, ukuran, dan bentuk serat. Ukuran dan bentuk serat sangat diperlukan untuk tujuan yang tertentu seperti pemrosesan dan perekatan dengan matriks [3]. Semakin kecil diameter serat maka semakin kuat bahan tersebut, karena minimnya cacat pada material [4].

Serat sabut kelapa mengalami perubahan diameter setelah direndam selama 3, dan 5 jam dalam larutan alkali dengan konsentrasi 5\%, 10\%, 15\%, dan $20 \%$. Degradasi diameter terbesar dipoeroleh pada serat sabut kelapa yang direndam selama 5 jam dalam larutan alkali $15 \%$ sebesar $56,08 \%$ [5].

Sebagaimana yang dikemukakan di atas bahwa telah dilakukan perlakuan serat sabut kelapa dengan tingkat konsentrasi alkali 5\%, 10\%, 15\%, dan 20\%. Maka dalam penelitian ini akan dilakukan penelitian lanjutan dengan memberi perlakuan serat sabut kelapa secara bertingkat dengan larutan kimia yang berbeda yaitu serat sabut kelapa direndam dalam larutan alkali kemudian kalium permanganat kemudian hidrogen peroksida.

Tujuan yang hendak dicapai dalam penelitian ini yaitu menentukan pengaruh lama perendaman serat sabut kelapa dalam larutan alkali dan hidrogen peroksida terhadap perubahan diameter serat sabut kelapa.

\section{Metode Penelitian}

\section{A. Bahan dan Alat}

Bahan yang digunalan dalam penelitian ini yaitu serat sabut kelapa, larutan alkali, larutan kalium permanganat, larutan hidrogen peroksida, dan aquades. Sedangkan peralatan yang digunakan yaitu seperangkat media perendaman, tungku, dan mikroskop digital.

\section{B. Pelaksanaan Penelitian}

Serat sabut kelapa direndam selama 1, 5, 7, 9, dan 11 jam dalam larutan alkali 10\% kemudian dikeringkan dalam tungku selama 5 jam pada $90^{\circ} \mathrm{C}$. Kemudian serat sabut kelapa direndam kembali selama 1, 5, 7, 9, dan 11 jam dalam larutan kalium permanganat dengan konsentrasi $0,5 \%$. Kemudian dikeringkan dalam tungku selama 5 jam pada suhu $90^{\circ} \mathrm{C}$. Setelah itu Serat sabut kelapa direndam sekali lagi selama 1, 5, 7, 9, dan 11 jam dalam larutan hidrogen peroksida dengan konsentrasi $10 \%$ kemudian dikeringkan dalam tungku selama 5 jam pada $90^{\circ} \mathrm{C}$.

Sebelum serat sabut kelapa direndam, terlebih dahulu diameternya diukur dengan menggunakan mikroskop digital dengan pembesaran 500X. Setelah proses perendaman, diameter serat sabut kelapa diukur kembali. Pengkuran diameter serat kelapa dilakukan sebanyak 5 kali, kemudian dirata-ratakan. Kedua hasil pengukuran tersebut akan dibandingkan dengan satu sama lainnya, kemudian akan dituangkan dalam bentuk tabel dan grafik.

Untuk menghitung diameter serat sabut kelapa digunakan persamaan 1 , dan persamaan 2 digunakan untuk mengetahui persentasi perubahan diameter serat sabut kelapa.

$$
d_{r}=\frac{d_{1}+d_{2}+d_{3}+d_{4}+d_{5}}{5}
$$

dimana $d_{r}$ adalah diameter rata-rata serat $(\mathrm{mm}), \mathrm{d}_{1}$ adalah diameter pengukuran pertama serat $(\mathrm{mm}), \mathrm{d}_{2}$ adalah diameter pengukuran pertama serat $(\mathrm{mm}), \mathrm{d}_{3}$ adalah diameter pengukuran pertama serat $(\mathrm{mm}), \mathrm{d}_{4}$ adalah diameter pengukuran pertama serat $(\mathrm{mm}), \mathrm{d}_{5}$ adalah diameter pengukuran pertama serat $(\mathrm{mm})$.

$$
d_{p}=\frac{d_{r b}-d_{r d}}{d_{r b}} \times 100 \%
$$

diaman $\mathrm{d}_{\mathrm{p}}$ adalah persesntasi perubahan diameter serat $(\%), d_{r b}$ adalah diameter rata-rata sebelum perendaman $(\mathrm{mm}), \mathrm{d}_{\mathrm{rd}}$ adalah diameter rata-rata sesudah perendaman (mm). 


\section{Analisa Data}

Metode yang digunakan dalam analisa yaitu metode deskriftif. Dalam metode ini, data-data yang diperoleh akan dituangkan dalam bentuk tabel atau gambar. Berdasarkan tabel dan gambar tersebut akan diambil kesimpulan dengan memperhatikan kecenderungan data pada tabel dan gambar tersebut.

\section{Hasil dan Pembahasan}

Perendaman serat sabut kelapa terdiri dari tiga tahap yaitu: (I) Perendaman dalam larutan $\mathrm{NaOH} 10 \%$, (II) Perendaman dalam larutan $\mathrm{KMnO}_{4} \quad 0,5 \%$, dan (III) Perendaman dalam larutan $\mathrm{H}_{2} \mathrm{O}_{2} \quad 10 \%$. Lama perendaman terdiri dari: 1 jam (H1), 5 jam (H5), 7 jam (H7), 9 jam (H9), dan 11 jam (H11).

Gambar 1 memperlihatkan diameter serat sabut kelapa (a) sebelum, dan (b) setelah direndam dalam larutan alkali $10 \%$.

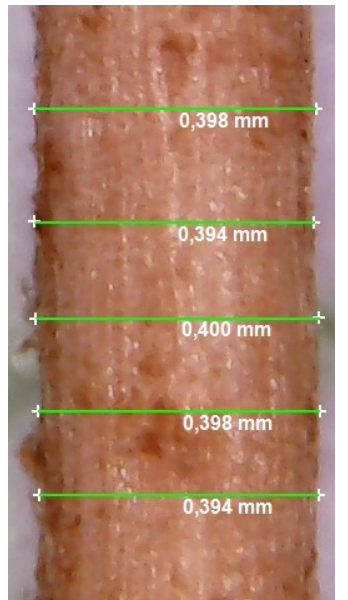

(a)

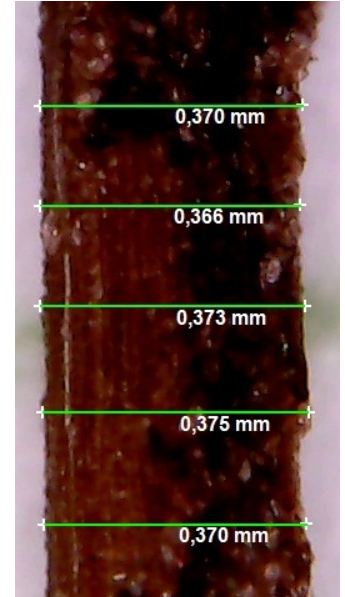

(b)
Gambar 1. Diameter Serat Sabut Kelapa Sebelum dan Sesudah

Perendaman dalam larutan $\mathrm{NaOH} 10 \%$ selama 1 jam

Diameter rata-rata serat sabut kelapa dihitung dengan menggunakan persamaan 1. Diameter rata-rata serat sabut kelapa sebelum direndam memiliki diameter ratarata $0,397 \mathrm{~mm}$ sedangkan setelah direndam selama 1 tahap I diameter rata-ratanya menjadi $0,371 \mathrm{~mm}$, Tahap II diameter rata-ratanya menjadi $0,284 \mathrm{~mm}$, dan Tahap III diameter rata-ratanya menjadi $0,277 \mathrm{~mm}$. Ukuran diameter serat sabut kelapa untuk perlakuan lainnya dapat dilihat pada Tabel 1.

Serat sabut kelapa normal atau tanpa perlakuan memiliki unsur-unsur atau partikel-partikel pengotor yang menempel pada permukaan serat. Namun, setelah direndam pengotor-pengotor tersebut terlepas dan/atau terlarut pada larutan yang digunakan sehingga menyebabkan diameternya berkurang [2]. Gambar 2 memperlihatkan dengan jelas bahwa diameter serat sabut kelapa mengalami degradasi atau pengurangan diameter setelah diberi perlakuan untuk semua tahap, baik perlakuan tahap I, II maupun perlakuan tahap III.

\begin{tabular}{|c|c|c|c|c|}
\hline \multirow{2}{*}{ Tama } & \multirow{2}{*}{$\begin{array}{c}\text { Sebelum } \\
\text { Perendaman }\end{array}$} & \multicolumn{4}{|c|}{ Sesudah Perendaman } \\
\cline { 3 - 5 } Perendaman & I & II & III \\
\hline H1 & 0,397 & 0,371 & 0,284 & 0,277 \\
\hline H5 & 0,360 & 0,273 & 0,294 & 0,242 \\
\hline H7 & 0,390 & 0,173 & 0,275 & 0,256 \\
\hline H9 & 0,382 & 0,191 & 0,237 & 0,205 \\
\hline H11 & 0,327 & 0,213 & 0,318 & 0,137 \\
\hline
\end{tabular}

Perubahan diameter serat sabut kelapa dihitung dengan menggunakan persamaan 2. Pada perendaman 1 jam (H1), diameter serat sabut kelapa mengalami penurunan diameter untuk semua perlakuan, dimana tanpa perlakuan diameter $0,397 \mathrm{~mm}$, dan setelah direndam hingga perlakuan ketiga (III) diameternya menjadi $0,277 \mathrm{~mm}$ atau pengurangan diameter sebesar $30,19 \%$ seperti yang diperlihatkan pada Tabel 2 . Persentasi tertinggi pengurangan diameter serat sabut kelapa dicapai pada perlakuan ketiga (III) pada perendaman 11 jam (H11) yaitu sebesar 58,08 \%. Hal ini menunjukkan bahwa semakin lama direndam semakin besar pengurangan diameternya. Semakin kecil diameter serat maka semakin kuat bahan tersebut, karena minimnya cacat pada material Akan tetapi semakin lama serat direndam juga akan mempengaruhi unsur-unsur serat seperti hemisellulosa, sellulosa, dan lignin. Hal ini akan mempengaruhi sifat mekanik serat. Ukuran dan bentuk serat sangat diperlukan untuk tujuan yang tertentu seperti pemrosesan dan perekatan dengan matriks [5].

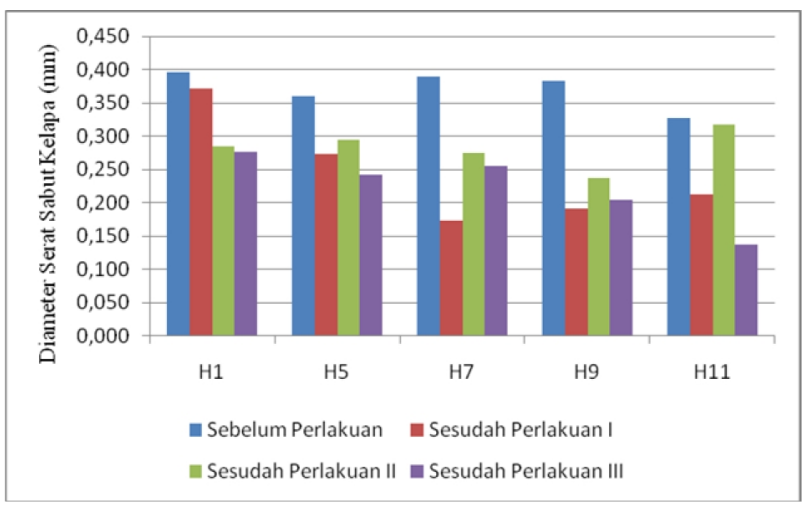

Gambar 2. Diameter Serat Sabut Kelapa 
Tabel 2. Pengurangan diameter Serat Sabut Kelapa (\%)

\begin{tabular}{|c|c|c|c|}
\hline \multirow{2}{*}{ Perlakuan } & \multicolumn{3}{|c|}{ Sesudah Perlakuan } \\
\cline { 2 - 4 } & I & II & III \\
\hline H1 & 6,55 & 28,38 & 30,19 \\
\hline H5 & 24,20 & 18,48 & 32,85 \\
\hline H7 & 55,66 & 29,42 & 34,50 \\
\hline H9 & 50,08 & 38,04 & 46,47 \\
\hline H11 & 34,70 & 2,69 & 58,08 \\
\hline
\end{tabular}

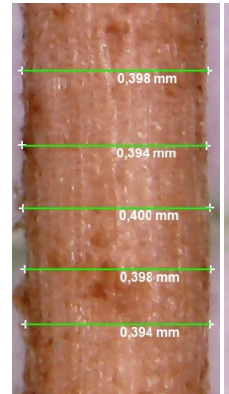

(a)

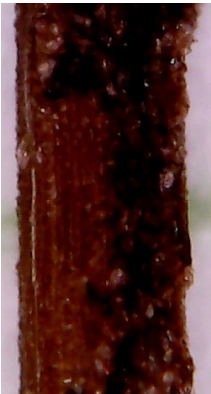

(b)

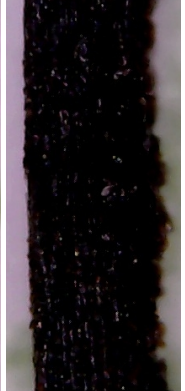

(c)

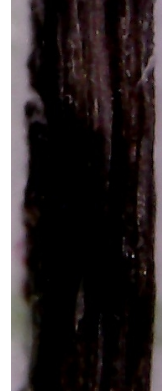

(d)
Gambar 3. Bentuk permukaan serat sabut kelapa

(a) sebelum perlakuan, (b) perlakuan I,

(c) perlakuan II, dan (d) Perlakuan III

Selain perubahan diameter, perendaman serat sabut kelapa dalam larutan kimia juga mempengaruhi bentuk dan warna serat seperti yang diperlihatkan pada Gambar 3. Sebelum direndam, serat sabut kelapa memiliki bentuk permukaan yang agak rata dan halus dengan warna agak cerah. Namun setelah diberikan perlakuan I, II, dan III bentuk permukaan serat agak kasar. Hal ini menunjukkan bahwa kotoran-kotoran yang melekat pada permukaan serat telah hilang dan terlarut dengan zat pelarut. Namun pada perlakuan III, bentuk permukaan serat sepertinya mengalami kerusakan. Hal ini menunjukkan bahwa perlakuan secara berulang juga tidak baik terhadap serat, karena akan merusak bentuk permukaan yang akan mempengaruhi kekuatan serat [6].

\section{Kesimpulan}

Sesuai dangan hasil dan pembahasan, dapat disimpulkan:

1. Perendaman serat sabut kelapa dalam larutan alkali, kalium permanganat, dan hidrogen peroksida mempengaruhi diameter serat sabut kelapa.

2. Persentasi tertinggi pengurangan diameter serat sabut kelapa diperoleh pada perlakuan III dengan lama perendaman 11 jam (H11) yaitu sebesar $58,08 \%$.

3. Perendaman serat sabut kelapa secara berulang menyebabkan permukaan serat sabut kelapa menjadi rusak.

\section{Ucapan Terima Kasih}

Terimakasih kami sampaikan kepada Direktorat Jenderal Pendidikan Tinggi atas pendanaan yang diberikan dalam menyelesaikan penelitian ini, Pimpinan Politeknik Negeri Ujung Pandang atas penggunaan fasilitas penelitian.

\section{Daftar Pustaka}

[1] Wagenugraha, 2008. Material Komposit Tangguh Berbasis Serat Alam. http://www.wagenugraha.wordpress.com/2008/09/21/ materikomposit-tangguh-berbasis-serat-alam/

[2] Arsyad, M. 2016. Efek Perendaman Serat Sabut Kelapa dalam Larutan Alkali Terhadap Daya Serap Serat Sabut Kelapa pada Matriks Poliester. Journal Intek 3(1):15-19

[3] Khalil, H.P.S.A. et all. 2006. Chemical Composition, Anatomy, Lignin Distribution, and Cell Wall Structure of Malaysian Plant Waste Fibers. J.Bioresources 1(2): 220 - 232.

[4] Hartanto, L., 2009. Study Perlakuan Alkali dan Fraksi Volume Serat terhadap Kekuatan Bending, Tarik, dan Impak Komposit Berpenguat Serat Rami Bermatrik Polyester BQTN 157 : Skripsi. Surakarta : Universitas Muhammadiyah Surakarta.

[5] Arsyad, M., dan Salam, A. 2017. Analisis Pengaruh Konsentrasi Larutan Alkali Terhadap Perubahan Diameter Serat Sabut Kelapa. Journal Intek 4(1):10-13.

[6] Arsyad, M., dan Wahyuni, N. 2015. Analisis Pengaruh Lama PerendamanSerat Sabut Kelapa Dalam Larutan NaOH Terhadap Perubahan Diameter Serat Sabut Kelapa. Jurnal Sinergi 2(13): 101-110. 